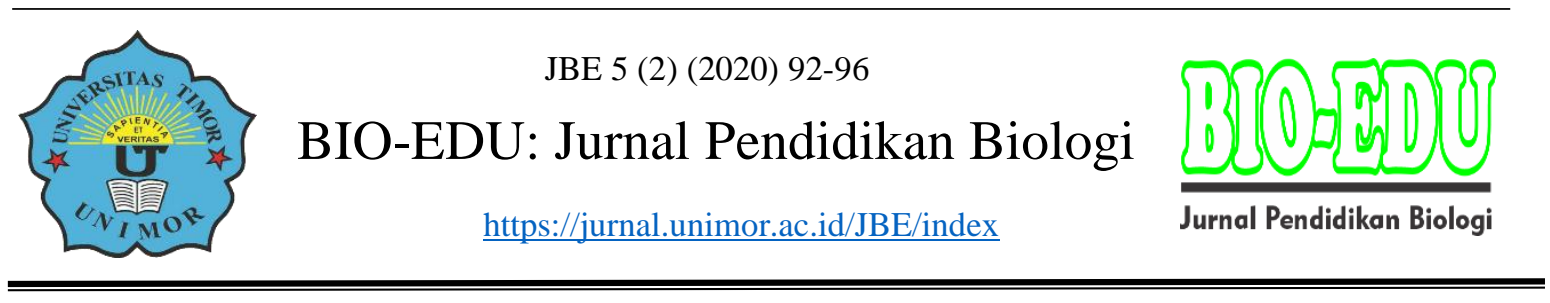

\title{
Pengaruh Minat Terhadap Hasil Belajar Siswa Menggunakan Metode TAI (Team Assisted Individualization) Pada Materi Dunia Tumbuhan
}

\author{
Florian Mayesti Prima R. Makin \\ Program Studi Biologi Universitas Timor, Kefamenanu \\ Email: florianmakin@gmail.com\
}

DOI: https://doi.org/10.32938/jbe.v5i2.568

\begin{abstract}
Abstrak
Tujuan penelitian ini adalah untuk mengetahui pengaruh minat belajar terhadap hasil belajar siswa menggunakan metode TAI (Team Assisted Individualization) pada materi dunia tumbuhan. Model Penelitian menggunakan Penelitian Tindakan Kelas (PTK) model Khemmis dan Mc. Taggart. Subyek penelitian adalah siswa kelas $\mathrm{X}_{1}$ SMA Pangudi Luhur Yogyakarta tahun ajaran 2012-2013 berjumlah 35 siswa. Instrumen pengumpulan data adalah tes dan non-tes. Presentase minat belajar siswa mencapai 83,34 $\%$ dan rata-rata peningkatan hasil belajar siswa pada aspek kognitif dari siklus I ke siklus II yaitu 40,3 menjadi 57,63. Hasil penelitian menunjukan peningkatan minat berpengaruh terhadap hasil belajar siswa pada aspek kognitif, yaitu semakin tinggi minat belajar siswa maka hasil belajar akan meningkat.
\end{abstract}

Kata kunci: Hasil belajar, metode TAI, minat

\section{Abstract}

The objective of this study was to investigate the effect of learning interest on the students' learning achievement by using the TAI (Team Assisted Individualization) method on the material of world of plants. The research was designed with Classroom Action Research (CAR) Khemmis and Mc. Taggart. The subjects of research were the students of class X1 of Pangudi Luhur High School Yogyakarta in the 2012-2013 academic years with 35 total numbers of students. The instruments of data collection are tests and non-tests. The percentage of students' interest reached $83.34 \%$ and the average of the increase of the students' learning achievement in the cognitive aspect from cycle I to cycle II was 40.3 to 57.63 . The finding showed that the learning interest affected the students' learning achievement in the cognitive aspect, when the students' interest in learning is high, the learning achievement will increase.

Keywords: Learning achievement, TAI methods, interests

\section{PENDAHULUAN}

Pendidikan merupakan faktor yang sangat penting bagi kelangsungan hidup manusia. Tingkat kemajuan suatu bangsa ditentukan oleh meningkatnya sumber daya manusia dan kualitas sumber daya manusia ditentukan dengan sistem pendidikannya. Patutlah setiap bangsa berusaha meningkatkan dan mengembangkan sistem pendidikan. Berdasarkan Undang-Undang RI No. 20 Tahun 2003 tentang Sistem Pendidikan Nasional, pendidikan adalah usaha sadar dan terencana untuk mewujudkan suasana belajar dan proses pembelajaran agar peserta didik secara aktif mengembangkan potensi dirinya untuk memiliki kekuatan spiritual, keagamaan, pengendalian diri, kepribadian, 
kecerdasan, akhlak mulia, serta keterampilan yang diperlukan dirinya, masyarakat, bangsa, dan negara.

Biologi merupakan salah satu mata pelajaran yang diajarkan di sekolah. Para siswa beranggapan bahwa mata pelajaran biologi adalah mata pelajaran yang sulit. Salah satu materi yang dianggap sulit adalah materi Dunia Tumbuhan. Kesulitan siswa disebabkan ketidakpahaman mereka tentang materi tersebut ditambah berbagai nama ilmiah dari setiap jenis tumbuhan yang perlu dipelajari. Hal ini ditunjukan dengan hasil belajar siswa aspek kognitif di SMA Pangudi Luhur Yogyakarta pada materi dunia tumbuhan adalah di bawah Kriteria Ketuntasan Minimal $(\mathrm{KKM}=75)$ yaitu 49,71. Hasil ini tentunya mempengaruhi minat belajar. Perolehan nilai di bawah KKM membuat siswa merasa tidak mampu dalam mata pelajaran tersebut sehingga minat belajar akan berkurang bahkan hilang.

Pembelajaran kooperatif merupakan model pembelajaran yang bisa diterapkan dalam biologi. Model ini lebih diarahkan kepada kelompok belajar siswa di kelas (Solihatin dan Rahardjo, 2007). Metode TAI (Team Assisted Individualization) adalah model pembelajaran kooperatif yang mengelompokan siswa berdasarkan kemampuan. Siswa berkemampuan lebih akan dikelompokkan dengan siswa yang berkemampuan sedang atau rendah. Siswa dapat belajar dengan baik apabila dijelaskan oleh teman sebaya mereka (Slavin, 2005). Tujuan penelitian ini adalah mengetahui pengaruh minat belajar terhadap hasil belajar siswa menggunakan metode TAI (Team Assisted Individualization) pada materi dunia tumbuhan.

\section{METODE}

Penelitian ini merupakan Penelitian Tindakan Kelas (PTK) model Kemmis dan Robbin Mc Taggart menggunakan metode TAI (Team Assisted Individualization). Pelaksanaan dirancang dalam dua siklus. Setiap siklus terdiri dari empat komponen yaitu perencanaan, tindakan, pengamatan, dan refleksi (Aqib, 2006). Subjek penelitian adalah siswa kelas XI SMA Pangudi Luhur Yogyakarta berjumlah 35 orang.

\section{HASIL DAN PEMBAHASAN}

\section{Minat Belajar Siswa}

Presentase minat tertinggi adalah 93,75\% dan presentase terendah adalah $40 \%$. Dari 30 siswa, 3 siswa memperoleh kriteria minat "sangat tinggi", 22 siswa memperoleh kriteria minat "tinggi", 5 siswa memperoleh kriteria minat "rendah", dan tidak ada siswa dengan kriteria minat "sangat rendah". Rata-rata nilai minat siswa setelah tindakan adalah 50,27 dengan ketuntasan klasikal/presentase kelas secara keseluruhan adalah 83,34 \% di mana hasil yang diperoleh ini sudah mencapai target keberhasilan yaitu $75 \%$. Dengan demikian kualifikasi minat belajar siswa dapat dikatakan sudah tercapai (Tabel 1).

Tabel 1. Hasil Analisis Minat Belajar Siswa.

\begin{tabular}{clc}
\hline No & \multicolumn{1}{c}{ Jenis Data } & Hasil Minat Belajar \\
\hline 1 & Presentase tertinggi & $93,75 \%$ \\
\hline 2 & Presentase terendah & $40 \%$ \\
\hline 3 & $\begin{array}{l}\text { Jumlah siswa dengan kriteria minat "sangat } \\
\text { tinggi" }\end{array}$ & 3 \\
\hline
\end{tabular}

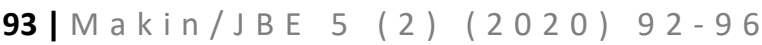




\begin{tabular}{clc}
\hline 4 & Jumlah siswa dengan kriteria minat "tinggi" & 22 \\
\hline 5 & Jumlah siswa dengan kriteria minat "rendah" & 5 \\
\hline 6 & $\begin{array}{l}\text { Jumlah siswa dengan kriteria minat "sangat } \\
\text { rendah" }\end{array}$ & Tidak ada \\
\hline 7 & Rata-rata nilai & 50,27 \\
\hline 8 & Ketuntaan klasikal & $83,34 \%$ \\
\hline 9 & Target keberhasilan & $75 \%$ \\
\hline 10 & Kualifikasi & Tercapai \\
\hline
\end{tabular}

Minat belajar siswa diperoleh dari hasil pengisian angket minat yang terdiri dari indikator yang meliputi rasa tertarik, senang, perhatian, semangat, puas, tidak merasa terpaksa, dan serius (Winkel, 1983). Indikator "kepuasan" memperoleh presentase tertinggi yaitu 76,67 \%. Besarnya presentase pada indikator "kepuasan" menunjukan bahwa siswa merasa puas dengan proses pembelajaran menggunakan metode TAI (Gambar 1). Tingginya minat belajar siswa menggunakan metode TAI dipengaruhi oleh motivasi. Motivasi yang dimaksud adalah motivasi ekstrinsik yang terkait dengan model penyajian materi pembelajaran. Fungsi motivasi dari dalam diri siswa adalah mendorong siswa untuk interes pada kegiatan yang akan dilakukan, menentukan arah perbuatan yakni ke arah tujuan yang hendak dicapai, dan mendorong siswa untuk pencapaian prestasi, yakni dengan adanya motivasi yang baik dalam belajar, maka akan menunjukan hasil belajar yang baik.

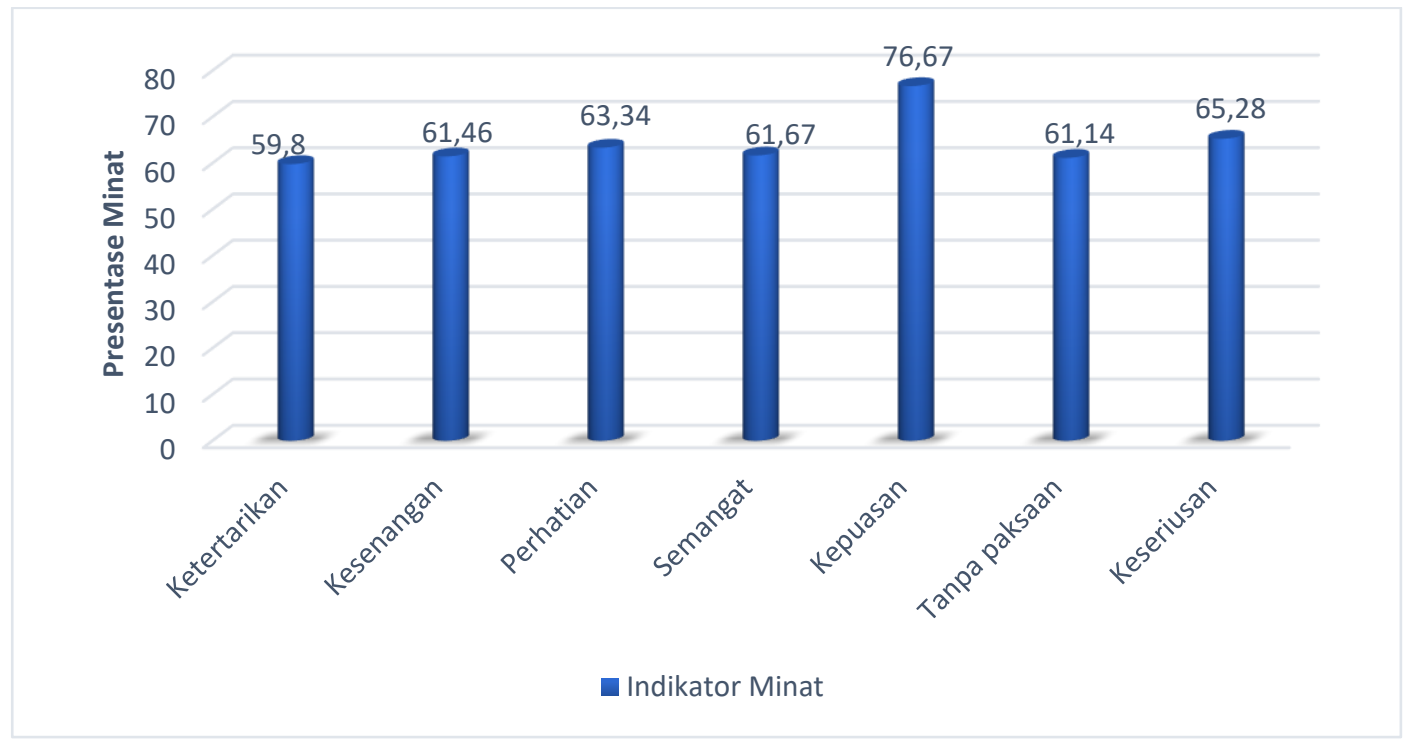

Gambar 1. Grafik Presentase Indikator Minat Belajar Siswa.

\section{Hasil Belajar Aspek Kognitif}

Nilai tertinggi yang diperoleh pada siklus I adalah 87 dan terendah adalah 24,3. Siswa yang tuntas $(\geq 75)$ adalah 5 siswa sedangkan 25 siswa lainnya tidak tuntas $(\leq 75)$. Nilai rata-rata kelas yang diperoleh adalah sebesar 40,3. Dengan demikian, presentase kelas yang diperoleh dari siklus I ini adalah sebesar 16,17\% di mana hasil ini belum mencapai target keberhasilan yaitu 75\%. Kualifikasi hasil belajar siswa pada aspek kognitif pada siklus I ini dapat dikatakan belum tuntas. Siklus II diperoleh nilai tertinggi adalah 88 dan nilai terendah adalah 24 . Siswa yang tuntas $(\geq 75)$ adalah 5 siswa 
sedangkan 25 siswa lainnya tidak tuntas $(\leq 75)$. Nilai rata-rata kelas yang diperoleh adalah sebesar 57,63. Dengan demikian, presentase kelas yang diperoleh dari siklus I ini adalah sebesar $16,17 \%$ di mana presentase yang diperoleh sama dengan pada siklus I karena jumlah siswa yang tuntas pada kedua siklus tersebut adalah sama yaitu 5 siswa. Hasil yang diperoleh pada siklus II juga belum mencapai target keberhasilan yaitu $75 \%$. Namun, dari hasil yang diperoleh siswa, terjadi peningkatan hasil belajar aspek kognitif dari siklus I ke siklus II dilihat dari rata-rata kelas yang diperoleh yaitu dari 40,3 menjadi 57,6 (Tabel 2).

Tabel 2. Hasil Belajar Siswa pada Aspek Kognitif Siklus I dan Siklus II.

\begin{tabular}{clcc}
\hline \multirow{2}{*}{ No } & \multicolumn{1}{c}{ Jenis Data } & \multicolumn{2}{c}{ Hasil } \\
\cline { 3 - 4 } & & Siklus I & Siklus II \\
\hline 1 & Nilai tertinggi & 87 & 88 \\
\hline 2 & Nilai terendah & 24,3 & 24 \\
\hline 3 & $\begin{array}{l}\text { Jumlah siswa yang tuntas } \\
(\geq 75)\end{array}$ & 5 & 5 \\
\hline 4 & $\begin{array}{l}\text { Jumlah siswa yang belum } \\
\text { tuntas }(\leq 75)\end{array}$ & 25 & 25 \\
\hline 5 & Rata-rata nilai & 40,3 & 57,63 \\
\hline 6 & $\begin{array}{l}\text { Ketuntasan } \\
\text { klasikal/presentase kelas }\end{array}$ & $16,17 \%$ & $16,17 \%$ \\
\hline 7 & Target keberhasilan & $75 \%$ & $75 \%$ \\
\hline 8 & Kualifikasi & Belum tuntas & Belum tuntas \\
\hline
\end{tabular}

Kategori hasil belajar aspek kognitif menunjukan 2 siswa memperoleh kategori "sangat baik" pada siklus I meningkat menjadi 3 siswa pada siklus II. Kategori hasil belajar "baik" diperoleh 12 siswa pada siklus I sedangkan pada siklus II 8 siswa. Kategori hasil belajar "cukup 7 siswa di siklus I dan 8 siswa pada siklus II. Kategori hasil belajar "kurang" 4 siswa siklus I dan 6 siswa pada siklus II. Perolehan Terdapat 5 siswa yang memperoleh kategori hasil belajar "sangat kurang" di siklus I dan siklus II (Grafik 2).

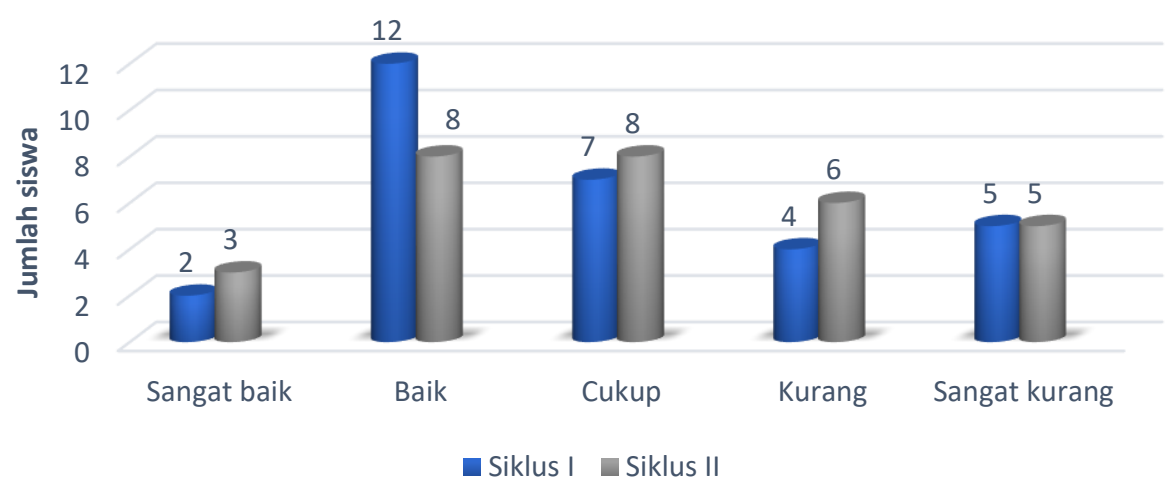

Gambar 2. Grafik Kategori Hasil Belajar Siswa pada Aspek Kognitif.

Faktor yang mempengaruhi hasil belajar pada aspek kognitif dibedakan menjadi dua faktor yakni internal dan eksternal. Faktor fisiologis dan psikologis tergolong faktor 
internal. Fisiologis adalah suatu kondisi yang berhubungan dengan jasmani siswa. Faktor psikologis berhubungan dengan keadaaan kejiwaan siswa, dalam hal ini adalah minat belajar siswa. Faktor psikologis juga dapat ditinjau dari kecerdasan siswa dan kemampuan kognitif. Kecerdasan berhubungan dengan kemampuan siswa menyesuaikan diri, menyelesaikan masalah dan belajar dari pengalaman. Kecerdasan dapat diasosiasikan dengan intelegensi. Siswa dengan nilai IQ yang tinggi umumnya mudah menerima pelajaran dan hasil belajarnya cenderung baik. Ranah kognitif merupakan kemampuan intelektual yang berhubungan dengan pengetahuan, ingatan, pemahaman dan lain-lain. Kemampuan siswa yang tinggi memungkinkan siswa dapat menggunakan pikirannya untuk belajar dan memecahkan persoalan-persoalan baru secara tepat, cepat, dan berhasil. Faktor eksternal yang berpangaruh antara lain interaksi antara guru-siswa dan hubungan antar siswa yang sehat. Peningkatan hasil belajar aspek kognitif siswa sesuai dengan tujuan pokok pembelajaran kooperatif (Trianto, 2009) yaitu memaksimalkan belajar siswa untuk peningkatan prestasi akademik dan pemahaman baik secara individu maupun secara kelompok.

\section{KESIMPULAN}

Hasil penelitian menunjukan peningkatan minat berpengaruh terhadap hasil belajar siswa pada aspek kognitif, yaitu semakin tinggi minat belajar siswa maka hasil belajar akan meningkat.

\section{DAFTAR RUJUKAN}

Aqib, Z. 2006. Penelitian Tindakan Kelas. Yrama Widya: Bandung.

Siregar, Eveline. 2010. Teori Belajar dan Pembelajaran. Ghalia Indonesia: Bogor.

Slavin, R.E. 2005.Cooperative Learning, Teori, Riset, dan Praktik. Nusa Media: Bandung.

Solihatin dan Rahardjo. 2007. Cooperative Learning Analisis model pembelajaran IPS. Bumi Aksara: Jakarta.

Winkel, W.S. 1983. Psikologi Pendidikan dan Evaluasi Belajar. Gramedia: Jakarta.

Winkel. 1989. Psikologi Pengajaran. Grafindo Persada: Jakarta.

Winkel. 1991. Psikologi Pengajaran. Grafindo Persada: Jakarta

Winkel. 2005. Psikologi Pengajaran. Media Abadi: Yogyakarta 